\title{
IMAGINATIVE CHILDHOOD: GOTHIC RECOLLECTIONS AND THE AMBIVALENT UNCANNY IN THE OCEAN AT THE END OF THE LANE
}

Fabian Quevedo da Rocha (UFRGS)

Recebido em 19 mai 2019. Fabian Quevedo da Rocha é Doutorando e Mestre Aprovado em 26 ago 2019. do Programa de Pós-Graduação em Letras da UFRGS na área de Estudos de Literatura, vinculada a linha de pesquisa Sociedade, (Inter)Textos Literários e Tradução nas Literaturas Estrangeiras Modernas. É graduado em Letras - licenciatura, com ênfase em Língua Inglesa pela Universidade Federal do Rio Grande do Sul e ministrante de curso presencial no Núcleo de Ensino de Línguas em Extensão (NELE) da mesma universidade. Seus temas de interesse são Literatura Inglesa do século XX, Literatura de Fantasia, Literatura Comparada e Literatura e Sociedade.

Abstract: The present article explores some Gothic traits in Neil Gaiman's novel The Ocean at the End of the Lane, relying on the concepts of excess and diffusion as proposed by Fred Botting, and the uncanny, as defined by Freud, as a means to investigate how Gothic elements, such as gloomy atmospheres and shapeshifting monsters, emerge in the narrative and how they may influence one's reading of the book towards the fantastic. Gaiman's novel is filled with images that stir the imagination and that seem to allude to the supernatural. In addition to that, the author is 
famous for writing multi-layered narratives that make room for a variety of readings, from the fantastic to the more realistic. As sources to our investigation, we rely on the Gothic studies of Fred Botting (1996), the concepts of the uncanny as discussed by Freud (1919), and also on Gaiman's considerations concerning his work. Based on the studies of these scholars and on a close reading of that the novel, we argue that it may be read in at least two ways: as a fantastic narrative in which the events presented may be seen as supernatural, or as a dramatic story that uses Gothic elements to obscure a dark narrative about a traumatic childhood. This article is also a study of how Gothic elements may be transformed and displaced in different narratives to represent and voice different cultural anxieties of their authors' contexts.

Keywords: Botting; Freud; Gothic literature; Neil Gaiman.

Resumo: O presente artigo explora alguns dos traços Góticos em O Oceano no fim do Caminho, de Neil Gaiman, com base nos conceitos de excesso e difusão, propostos por Fred Botting, e de inquietante, como definido por Freud, a fim de investigar como elementos Góticos, tais como atmosferas sombrias e monstros metamorfos, surgem na narrativa e como eles podem influenciar uma leitura fantástica da obra. O romance de Gaiman é repleto de imagens que atiçam a imaginação e parecem aludir ao supernatural. Além disso, o autor é famoso por escrever narrativas multicamadas que possibilitam diferentes leituras, da fantástica às mais realistas. Como fontes para a nossa investigação, baseamo-nos nos estudos Góticos de Fred Botting (1996) e no conceito de inquietante propostos por Freud (1919), e nas considerações de Gaiman sobre sua obra. Com base nos estudos desses intelectuais e em uma leitura atenta do romance, propomos que o mesmo pode ser lido de no mínimo duas maneiras: como uma narrativa fantástica na 
qual os eventos apresentados podem ser vistos como sobrenaturais, ou como uma história dramática que usa elementos Góticos para obscurecer uma narrativa sombria sobre uma infância traumática. Este artigo é, também, um estudo de como elementos Góticos podem ser transformados e realocados em diferentes narrativas a fim de representar e dar voz aos diferentes anseios culturais do contexto de seus autores.

Palavras-chave: Botting; Freud; Literatura Gótica; Neil Gaiman.

\section{INTRODUCTION}

Fred Botting (1996), argues that Gothic writing is a writing of excess. In this sense, the elements from The Ocean at the End of the Lane discussed and called "Gothic" in this article appeal to different forms of excess, mainly to the excess of imagination and emotion. Ambivalence and uncertainty are also key concepts for the discussions in this work: the events taken from the novel and presented here should be seldom taken for granted, but rather seen under the skeptical lens of suspicion. In addition to that, Gaiman's novel will be analyzed under the light of a further concept proposed by Botting, that of diffusion. In this sense, The Ocean at the End of the Lane is seen here not as a Gothic novel per se, but rather as a fantasy book filled with Gothic features.

As for the diverse meanings of the uncanny, in this article, the term is deeply connected to "that class of the frightening which leads back to what is known of old and long familiar." (FREUD, 1919, p.219) Therefore, it concerns the ambivalent meaning that the German word Unheimlich may assume. As Freud suggests, the word Unheimlich is the opposite of the word Heimlich, which may 
be translated as "homely". Thus, something that is Unheimlich (unhomely) is something that is not familiar. In this sense, "we are tempted to conclude that what is 'uncanny' is frightening precisely because it is not known and familiar." (1919, p.219) Curiously enough, some of the definitions that Freud discusses in his work for the term Heimlich seem to challenge such an assumption. According to the data the author presents, these are some of the meanings the word Heimlich may assume: something that belongs to the house, that is not strange, but familiar, tame, intimate, friendly, etc; something that is concealed, kept from sight, so that others do not get to know of or about it, withheld from others; something that should have remained secret and hidden but that has not.

A tricky characteristic of the words Unheimlich and Heimlich that Freud cleverly points out, and that is central to this research, has to do with the fact that there are instances in which both words come to mean the same thing. To use Freud's words, "[w]hat is heimlich thus comes to be unheimlich." (1919, p.224)

Having concluded these brief terminological remarks, we would like now to pose some considerations about Gaiman's work that will be the focus of this essay. The Ocean at the End of the Lane is a novel about memories, childhood memories to be more specific. It is a book about recollections that come to us when we are least expecting and that stir feelings of a long gone past, bringing with them images from the back of our minds that we thought were forgotten. It is also a book about fears, the power of imagination, and how the latter can help us overcome the first. In this research, we explore the Gothic elements in Gaiman's novel, such as the presence of a gloomy atmosphere and shape-shifting monsters, as 
a means to better understand what their function and contribution to the narrative is. In it, we also investigate how such elements may influence one's reading of the book towards the fantastic.

\section{GOTHIC RECOLLECTIONS}

Recollections play an important role in The Ocean of the End of the Lane. The book, in its almost entirety, revolves around them. However, the recollections in the novel are of a specific kind: they are childhood memories. The novel starts with the narrator, an unnamed middle-aged man, driving adrift along rural Sussex roads after attending a funeral. He is supposed to head to his sister's house, but he finds himself going somewhere else: to a house that had not existed for decades. He feels as if he should turn around and leave the past undisturbed. He is prevented by his curiosity, though. When he reaches the place where he had lived as a young boy, he slows his car down, parks it in front of a residence, and starts to study it. The house he sees is not the one he had spent his childhood in, but the one his parents had built when he was a teenager. He does not know who lives there now and he does not seem to care about the place: "I stared at the house, remembering less than I had expected about my teenage years: no good times, no bad times. I'd lived in that place, for a while, as a teenager. It didn't seem to be any part of who I was now." (GAIMAN, 2013, p.4) The narrator, then, drives away apparently trying to delay his going to his sister's house, because there "[he] would talk to people whose existence [he] had forgotten years before [...] [he] would talk about the departed; [he] would remember the dead." (GAIMAN, 2013, p.4) As he drives away from the town, the opposite way he should 
have been traveling, he feels good; and as he goes on, he seems to be drawn to a place that makes his memories stir inside his head. He feels as if he had traveled in time. When he finally reaches the end of the lane, what he finds there is a dilapidated red-brick house: the Hempstocks' farmhouse. He wonders whether after all these years someone is still living there. The thought sounds unlikely to him, but, as far as he can remember, the Hempstocks had always been unlikely people. He decides to knock at the door and check it out, and as he stands at the threshold, his childhood memories start to come back:

I had been here, hadn't I, a long time ago? I was sure I had. Childhood memories are sometimes covered and obscured beneath the things that come later, like childhood toys forgotten at the bottom of a crammed adult closet, but they are never lost for good." (GAIMAN, 2013, p.5)

It is curious to notice how the memories of the narrator's childhood seem to be much stronger than the ones of his teenagehood. If the latter does not seem to be any part of who he presently is, the first, on the other hand, is deeply imprinted on him. Why should that be so? It has to do, to a large extent, with what happened to him when he was seven, the year he met Lettie Hempstock, the strange girl who lived in the farm at the bottom of the lane. So big was the importance of The Hempstocks in his life, that he was unconsciously drawn to their old house. As he enters it, he meets whom he believes to be Mrs. Hempstock, Lettie's mother. They talk for a while and he enquires whether Lettie is there or not. She is not. He remembers, then, that she had gone somewhere, but he cannot recall where. It was somewhere a long way away. 
He asks, then, if he can go to the duck pond. He remembered the place was of distinct importance to Lettie; she even had a special name for it, though he could not recall it. Little by little, the narrator seems to be engulfed by memories: "[...] standing in that hallway, it was all coming back to me. Memories were waiting at the edges of things, beckoning to me. Had you told me that I was seven again, I might have half-believed you, for a moment." (GAIMAN, 2013, p.7)

A careful reading of the prologue of The Ocean at the End of the Lane is relevant not only to the discussions this research proposes, but also to a broader understanding of the novel in the sense that it calls readers' attention to the relevance of the events that will be presented in the next chapters to the narrator's life. In addition to that, the prologue sets the tone to a major shift in the narrative: a change in the perspective through which it is presented, or rather, a change in focalization. From chapter I on, the story is presented to the readers mostly through the perspective of the narrator as a child. Therefore, most of the narrative is given us through the point of view of a seven-year-old boy, which means that the events are introduced to us the way this child perceives them. Besides that, the gloomy and mysterious atmosphere that is created in the prologue (and intensified in the rest of the narrative), as Botting (1996) suggests, signals the disturbing return of pasts upon presents. The prologue closes with the narrator staring at the duck pond and recalling the name his friend, Lettie, had for it: "[i]t was the ocean. Lettie Hempstock's ocean. I remembered that, and, remembering that, I remembered everything." (GAIMAN, 2013, p.8)

As it was stated above, from chapter I on, there is a change in focalization. Even though at times the focalization returns to the 
narrator as an adult, during most of the narrative the focalizer is his childhood self, a seven-year-old boy. It is important to highlight, however, that although there is no change in the person who narrates the story, for the man in the prologue and epilogue, and the boy in chapters I to XV are the same person, there is a considerable difference between the ways an adult and a child perceive the world and its happenings. In this sense, an analysis of the character of the narrator as he was a young boy is pertinent to the discussions proposed in this work.

Some of the first things learned about this young boy is that he is probably friendless and that he fills this gap with stories, fantasy stories to be more specific. Besides that, books seem to play a central role in his life: rather than being simply things with which he can distract himself; they are real humans that offer him a feeling of safety that he does not experience with "other people":

Nobody came to my seventh birthday party. [...] I was sad that nobody had come to my party, but happy that I had a Batman figure, and there was a birthday present waiting to be read, a boxed set of the Narnia books, which I took upstairs. I lay on the bed and lost myself in the stories. I liked that. Books were safer than other people anyway. [...] I made friends slowly, when I made them. (GAIMAN, 2013, p.9-8 - our emphasis)

Given the passage below, it is possible to reason that this boy spends considerable amounts of time involved in activities related to imagination. This notion is reinforced several times throughout the narrative, however, it is in the following passage from chapter II that this idea becomes more evident: "I was not 
happy as a child, although from time to time I was content. I lived in books more than I lived anywhere else." (GAIMAN, 2013, p.13 - our emphasis) One could argue, however, that being imaginative is not an uncommon trait among children, mainly among children that are fond of reading, which we believe is true. However, calling attention to such characteristics of the boy is important in this research in the sense that it is relevant to a broader understanding of the outcome of the novel. As it will be seen later in this work, the boy's narrative at times seems to be imbued with an excess of imagination that exceeds reason, which goes towards one of Botting's conceptions of the Gothic: "[a]ssociated with wildness, Gothic signified an over-abundance of imaginative frenzy, untamed by reason and unrestrained by conventional eighteenth-century demands for simplicity, realism or probability."(1996, p.2)

The supernatural and uncanny incidents in The Ocean at the End of the Lane start to take place after the narrator discovers that his family is having financial problems. Consequently, as a way to complement the income, the boy's parents start to receive lodgers in one of the bedrooms of the house, the narrator's bedroom. The boy does not feel pleased with the decision:

My former bedroom at the top of the stairs was let out, and a variety of people passed through it. I viewed them all with suspicion: they were sleeping in my bedroom, using my little yellow basin that was just the right size for me. There had been a fat Austrian lady who told us she could leave her head and walk around the ceiling; an architectural student from New Zealand; an American couple whom my mother, scandalized, made leave when 
she discovered they were not actually married; and, now, there was the opal miner. (GAIMAN, 2013, p.14)

It seems as if the narrator sees the lodgers as invaders: they came out of nowhere, claimed his haven for themselves and, to make matters worse, were violating his precious belongings. The opal miner was the worst of them: besides being living in the boy's bedroom, he had also accidentally killed the narrator's kitten on the day of his arrival.

One morning, however, someone reported having seen the boy's family car abandoned at the bottom of their lane. When his father and he drive with the police to the place where the car was said to be, they find the opal miner's dead body on its back seat. Interestingly enough, when a policeman tells the narrator that it would be necessary that they find somewhere for the boy to stay so that he would not be in the way during the investigation, a mysterious girl appears and tells them that he could stay at her family's farmhouse. This girl is Lettie Hempstock, daughter of Mrs. Hempstock, and granddaughter of Old Mrs. Hempstock, a peculiar family that, as the boy soon discovers, has supernatural powers: all the three of them seem not only to be omniscient, but also to be able to read people's minds and influence their thoughts. Curiously enough, the boy does not seem bothered by their strange powers, but rather delighted with their manners and way of life, so much so that when his father comes to the Hempstock's farm to pick up his son and the boy reflects upon the incidents of the day, he does not seem bothered nor shocked with everything that has happened: " I had found a special place, and made a new friend [...]." (GAIMAN, 2013, p.24) 
The supernatural, sensational and terrifying incidents in Gothic narratives, as Botting (1996) believes, may be either imagined by the characters or not. In this sense, the strange events that take place after the opal miner's suicide may be read as either real incidents or products of a child's overexcited imagination. In this work, we try to explain how the latter is possible. The Gothic preternatural happenings in The Ocean at the End of the Lane often take place after the narrator is put through some sort of situation involving tension: family problems, strange deaths, bad dreams, etc. Lettie herself starts to appear in the narrative after the boy discovers a dead body inside his family car. More than that, the girl tends to appear when the narrator needs comfort or help to figure out a difficult or strange situation, but he can find neither in his own house. This notion may be made clearer in the following passage that takes place after the boy wakes up from a terrible dream:

I wanted to tell someone about the shilling, but I did not know who to tell. I knew enough about adults to know that if I did tell them what had happened, I would not be believed. Adults rarely seemed to believe me when I told the truth anyway. Why would they believe me about something so unlikely? [...] Lettie Hempstock was standing at the bottom of the drive, beneath the chestnut trees. She looked as if she had been waiting for a hundred years and could wait for another hundred. She wore a white dress, but the light coming through the chestnut's young spring leaves stained it green. I said, "Hello." She said, "You were having bad dreams, weren't you?" I took the shilling out of my pocket and showed it to her. "I was choking on it," I told her. "When I woke up.But I don't know how 
it got into my mouth. If someone had put it into my mouth, I would have woken up.It was just in there, when I woke." (GAIMAN, 2013, p.28-29)

When the narrator asks the girl whether these strange happenings have to do with the man that had died, she says it has, however, it is not him that is causing them. His death had been the propeller, but what was behind these events was something else. Lettie tells the boy about three other strange cases that have recently happened in their neighborhood: a man dreamt he was turned into money and now he sees weird things in mirrors, a woman has gone mad and refuses to leave her bed, afraid someone may take the money she hides in it, a family is having financial problems and the husband dreamt his wife was doing bad things to earn money just to wake up and find lots of folded-up ten-shilling notes in her handbag. The wife does not know where the money came from. Hearing Lettie's accounts, the narrator realizes that all the strange occurrences are connected to money. In addition to that, it is interesting to note that his family has been having money issues and also that the opal miner committed suicide because he had lost all his money. Faced with this all, the narrator is scared. Lettie comforts him by telling him that everything can be sorted out and that she will make sure he will be safe. The boy feels good in the girl's company, and when they get to her farmhouse, such feeling increases. There he feels cared for and important:

Old Mrs. Hempstock said, "Go and get your mother. She's doing laundry." Then, to me, "You shall help me with the daffs." I helped her put the flowers into the vases, and she asked my opinion on where to put the vases in the kitchen. We placed the 
vases where I suggested, and I felt wonderfully important. [...] The old woman gave me a lump of honeycomb, from the Hempstocks' own beehive, on a chipped saucer, and poured a little cream over it from a jug. I ate it with a spoon, chewing the wax like gum, letting the honey flow into my mouth, sweet and sticky with an aftertaste of wildflowers. (GAIMAN, 2013, p.33-34)

With the aid of Lettie's mother and grandmother, the girl makes preparations to start the quest to stop the entity that is causing trouble. Lettie's mother believes it is not a problem if the boy goes along with her daughter. He wants to go. Lettie wants him to go. Old Mrs. Hempstock, however, is against the idea, but after Lettie's insisting on the matter, the old woman relents but warns them about the dangers. The chapter closes with what sounds like a bad omen:

"Don't take the boy," said Old Mrs. Hempstock. "Asking for trouble, that is."I was disappointed. "We'll be fine," said Lettie. "I'll take care of him. Him and me. It'll be an adventure. And he'll be company. Please, Gran?" I looked up at Old Mrs. Hempstock with hope on my face, and waited."Don't say I didn't warn you, if it all goes wobbly," said Old Mrs. Hempstock."Thank you, Gran. I won't. And I'll be careful." Old Mrs. Hempstock sniffed. "Now, don't do anything stupid. Approach it with care. Bind it, close its ways, send it back to sleep." "I know," said Lettie. "I know all that. Honestly. We'll be fine."That's what she said. But we weren't. (GAIMAN, 2013, p.35)

If the idea that the Gothic supernatural events in Gaiman's narrative are the product of an overexcited mind is accepted, the boy's desire to join Lettie in the quest to stop the creature that is 
making people have issues with money may be seen as a metaphor: in order to go through the difficulties and changes connected to his family's new financial condition, the boy must destroy the imaginary monster he believes is responsible for them. Lettie, in this sense, may be seen as the one who guides and helps him through such hardships. Two points that may corroborate with such theory have to do with the fact that the girl is considerably older than him (she is 11, while he is 7) and also that he feels safe and important when he is with her and her family. Soon after Lettie and the narrator manage to send the troublesome creature back to sleep, things start to get financially better for the boy's family: when the narrator wakes up in the morning after his adventure with Lettie, he discovers that his mother has found a job.

\section{THE AMBIVALENT UNCANNY}

Concerning the many considerations that Freud (1919) poses about the term "uncanny", the first one to appear in his essay associates it to what is frightening, to what arouses dread and horror. However, one of the chief obstacles in the study of the term is connected to the idea that the very notion of frightening is relative: people's perceptions of what is dreadful may vary considerably, thus what one's conception of uncanny is may not be shared by others. In addition to that, there is also the semantic factor: the term uncanny is just an approximate translation of the German word unheimlich; besides that, Freud calls attention to the notion that many languages seemingly do not have a word that conveys the same shade of meaning that the German term does, which, as we will try to explain, may be related to its ambivalence. 
To make this idea clear, it is important to call attention to the fact that the word unheimlich is the opposite of heimlich. One of the many dictionary definitions presented by Freud of such antonym says that something heimlich is something that belongs to the house, something familiar, tame, intimate, friendly. In other words, something heimlich is something that is not strange. It could be argued, then, that something unheimlich (or uncanny) is frightening precisely because it is unknown, because it is strange. However,

among its different shades of meaning the word 'heimlich' exhibits one which is identical with its opposite, 'unheimlich'. What is heimlich thus comes to be unheimlich. [...] In general, we are reminded that the word 'heimlich' is not unambiguous, but belongs to two sets of ideas, which, without being contradictory, are yet very different: on the one hand it means what is familiar and agreeable, and on the other, what is concealed and kept out of sight. (FREUD, 1919, p.224)

The uncanny in The Ocean at the End of the Lane, thus, arises from antithetical sources: at times the feeling derives from elements that are not familiar to the narrator, this is, that come from outside, that do not "belong to the house" (unheimlich), but at other times it comes from something happening inside the narrator's home (heimlich), something that should have remained secret and hidden but that has not. It is also curious to note that there are instances in which something supernatural and unfamiliar happens and does not produce an uncanny impact on the narrator, but rather makes him feel safe and "at home".

An example of the first instance of the uncanny, mentioned in the paragraph above, happens shortly after the narrator and Lettie 
defeat the "monster" that is believed to be causing people to have money problems: when the boy returns home from Lettie's house, he realizes there is a small hole in the sole of his foot that happens to be in the exact spot he had felt pain during the confrontation with the creature. As he analyzes it, he notices there is something inside the hole. $\mathrm{He}$, then, decided to remove from his foot whatever is inside it, goes to the bathroom and with the help of a pair of tweezers and hot water, removes the thing. It is a worm. As he stares at it, it seems as if a small part of the creature is missing, but he is not sure. The way the boy proceeds next is worth noting since he will associate it with his future problems:

I did not want to kill it-I did not kill animals, not if I could help it-but I had to get rid of it. It was dangerous. I had no doubt of that. I held the worm above the bath's plug hole, where it wriggled, under the scalding water. Then I let it go, and watched it vanish down the drain. (GAIMAN, 2013, p.49-50)

The next morning his mother tells him she has found a job and that she has hired someone to look after him and his sister. Her name is Ursula Monkton, she has excellent references, and she is going to live with them. As the narrator has a history of bad experiences with housekeepers, he is not happy with the idea and takes it with suspicion. When his mother finishes, he takes a book and goes to their garden to read it. He reads about the Egyptian myth of Hathor, a shapeshifter goddess that nearly killed all humanity before she was stopped by Ra. When he returns to the house, the new housekeeper is already there. He is afraid of the woman from the moment he puts his eyes on her: 
I just looked at her, all grown-up and blonde, in her gray and pink skirt, and I was scared. Her dress wasn't ragged. It was just the fashion of the thing, I suppose, the kind of dress that it was. But when I looked at her I imagined her dress flapping, in that windless kitchen, flapping like the mainsail of a ship, on a lonely ocean, under an orange sky. (GAIMAN, 2013. p.54)

It is interesting to notice how the boy's description and impression of the woman resemble his description of the monster Lettie and he had faced the day before:

I thought I was looking at a building at first: that it was some kind of tent, as high as a country church, made of gray and pink canvas that flapped in the gusts of storm wind, in that orange sky: a lopsided canvas structure aged by weather and ripped by time. [...] Its face was ragged, and its eyes were deep holes in the fabric. There was nothing behind it, just a gray canvas mask, huger than I could have imagined, all ripped and torn, blowing in the gusts of storm wind. (GAIMAN, 2013, p.40-41)

Feeling threatened by the arrival of the new housekeeper and perhaps influenced by the myth of Hathor, the narrator associates the woman with the creature he had supposedly destroyed with Lettie. It may be argued, then, that when the narrator feels he is being threatened or needs to understand something, his imagination tends to lean towards the supernatural. The unsettling feeling arising from Ursula's arrival may be connected to the notion that something uncanny may be something that comes from outside, and also to Botting's (1996) idea of the disturbing return of pasts upon presents deriving from the unknown. In addition to that, it 
is also important to note that when the supernatural happenings arise in the narrative, they usually function as a way to deviate the readers' attention from another story that permeates the work, a secret narrative that, as Ricardo Piglia (2011) states, is constructed in the interstices of a visible narrative. This secret narrative is built in a fragmentary way, through suggestiveness and allusion.

A further instance of the uncanny in Gaiman's novel derives from something happening inside the narrator's house, but that was being kept secret. Although the uncanny feeling does not derive from supernatural elements this time, it seems to produce an even greater impact on the narrator, which may be due to the secret he discovers in his own house threatens to destroy his family:

I was not sure what I was looking at. My father had Ursula Monkton pressed up against the side of the big fireplace in the far wall. He had his back to me. She did too, her hands pressed against the huge, high mantelpiece. He was hugging her from behind. Her midi skirt was hiked up around her waist. [...] I was no longer scared by what had happened in the bathroom; now I was scared by what it meant that my father was kissing the neck of Ursula Monkton, that his hands had lifted her midi skirt above her waist. My parents were a unit, inviolate. The future had suddenly become unknowable: anything could happen: the train of my life had jumped the rails and headed off across the fields and was coming down the lane with me, then. (GAIMAN, 2013, p.79-80)

Confronted with such scene, the boy is taken aback by a variety of emotions: puzzlement, for his seven-year-old mind is still unable to fully comprehend what that all means; despair, for 
whatever he is seeing means, it also means that his parents are not an inviolate unit anymore; and guilt, because he believes he is responsible for Ursula Monkton's sudden appearance: "Ursula Monkton was my fault, I was certain of it, and I would not be able to get rid of her by flushing her down a plug hole, or putting frogs in her bed." (GAIMAN, 2013, p.55) The narrator believes Ursula Monkton is the monster Lettie and he had supposedly destroyed. He believes he had brought the creature with him in the form of the worm he removed from his foot. The worm he had refused to kill was now back in the form of his housekeeper. The woman was destroying his family and it was all his fault. To try to figure out what is happening, the narrator runs away from his house seeking the aid of Lettie and her family. The boy hopes they can help him understand, as they often do, what is going on. More than that, he runs to them because he knows that in Lettie's house he is safe, cared for, and understood.

It is curious, however, that to find comfort and to feel safe, the narrator has to leave his house. Not being able to find such things at home, he has to look for them outside. It does not matter that Lettie Hempstock and her family are able to read people's minds and influence their thoughts, it does not matter that Lettie's grandma remembers when the Moon was made, it does not matter that their farm is in the Domesday book, nor that the girl's family had come to England when she was just a baby across a pond-sized ocean, from the old country. It may be argued, then, that the comfort and safety the narrator needs arise from something that is not present at home. It is an instance in which what is unheimlich, comes, thus, to be heimlich. 
To this point, Gaiman's narrative has presented instances in which (1) Gothic unheimlich elements appear and provoke an uncanny effect in the narrator, (2) non-Gothic, heimlich, elements arise and impact the narrator with a somehow stronger sense of the uncanny, and (3) instances in which Gothic unheimlich elements appear and provide the narrator with comfort and safety. The elements of the first and third instances, we argue, serve, to a considerable extent, to help the narrator understand and explain things his child's mind is still unable to fully comprehend, as well as to deviate the reader's attention from elements of the third instance, which constitute a hidden narrative that is only hinted at.

When, towards the end of the narrative, Lettie, her family, and the narrator, after a series of other supernatural events, manage to restore things to their natural order, the girl leaves the narrative. The boy is told that his friend had to go to Australia; however, he remembers, or seems to remember, things differently: "A small part of my mind remembered an alternate pattern of events and then lost it, as if I had woken from a comfortable sleep and looked around, pulled the bedclothes over me, and returned to my dream." (GAIMAN, 2013, p.168) Moments after that, the boy learns from his mother that Ursula had to leave due to pressing family matters.

The book finishes with the narrator as an adult taking the narrative over again and revealing that years after the incident with Ursula, when his sister and he were both grown-ups, she confided to him that she believed Ursula had not left due to family issues, but rather that their mother had fired her because the housekeeper and their father were having an affair. The narrator, then, argues that it was possible. He also reveals that, as a consequence of the 
events that took place during the period Ursula lived in their house, his father and he had not been in good terms for years, and that he is certain that he had been a disappointment to him.

It is only in the final pages of the book that the hidden story appears on the surface, opening further space for interpretations that had been only being suggested throughout the narrative. When the narrator, that had been lost in memories since the prologue of the book, finally comes back from his waking dream in the epilogue of the work and finds himself still sitting by the duck pond, he wants to know what all that meant. The answers he gets make room for seeing Lettie and all the supernatural adventures they had together as a metaphor he needed to go through the hardships of his childhood, a metaphor that helped and still seems to help him fill the empty spaces in his life, so much so that, as it is learned in the epilogue, he revisits the place from time to time whenever he has to figure things out. When he finally stands up to leave the place, he approaches the pond and says out loud: "Lettie, [...] thank you for saving my life." (GAIMAN, 2013. p.176)

\section{FINAL CONSIDERATIONS}

During the course of this work, we have analyzed how Gothic elements appear in The Ocean at the End of the Lane and how these elements construct meaning in the narrative. Even though Gaiman's work is not a Gothic novel per se, the way the writer decided to build his narrative makes room not only for supernatural readings but also for Gothic studies. The Gothic potential of The Ocean at the End of the Lane is connected, on one hand, to Botting's concept of diffusion, which means that Gothic traces are commonly found in 
different literary genres and media. On the other hand, it has also to do, to a large extent, with the scholar's concept of excess: in Gothic productions, "imagination and emotional effects [frequently] exceed reason" while "ambivalence and uncertainty [tend to] obscure single meaning" $(1996$, p.2) In this sense, Gaiman's work is a fantasy novel permeated with Gothic motifs that were transformed and displaced in order to represent and voice the different cultural anxieties of the author's time. Therefore, the importance of this study has to do with the idea that it is an attempt to better understand how the Gothic mode operates in the literature of our time.

The Ocean at the End of the Lane is, on its surface, about the childhood of an imaginative boy that, when confronted with situations that he still cannot fully comprehend, seeks comfort and safety in the realm of the fantastic, be it through literature or his imagination. By resorting to such methods, the boy manages to defeat his demons and overcome his fears. Under its surface, however, lies a secret and much darker tale, the story of how a sevenyear-old boy endured the hardships of growing up while seeing the relationship of his parents slowly crumbling and transforming his once-safe home into a hostile place where he no longer feels loved and cared for.

By carefully adding Gothic patterns and motifs to his narrative, Gaiman managed to create an ambivalent narrative that maintains the readers' attention while evoking curiosity, nostalgia, compassion, pity, amazement, and a series of other feelings in them. The author's craft not only makes room for wondering what is real and what is imagined in his narrative, but it also raises questions concerning what the boundaries between what is real and what 
is imagined are and whether that should matter. Gaiman's novel, in the sense that among the multiple readings The Ocean at the End of the Lane allows, the cruelest of them is the one that most resembles something that could have happened in real life, stands as a reminder that, at times, reality may be darker than fiction.

All things considered, the techniques Gaiman applied to his novel helped him create a narrative that resembles an ocean of memories and feelings; when it is stirred, its mighty waves come crashing with a powerful impact on the readers.

\section{REFERENCES}

BOTTING, Fred (1996). Gothic. London: Routledge.

FREUD, Sigmund (1919). The "uncanny". In: FREUD, Sigmund (Ed.). The standard edition of the complete psychological works of Sigmund Freud, volume XVII (1917-1919): An infantile neurosis and other works. London: Vintage, p.217-256.

GAIMAN, Neil (2013). The ocean at the end of the lane. New York: Harper Collins. . "The ocean at the end of the lane" / Talks at Google. (ca. 54 min 52 s). In https://www.youtube.com/watch?v=1Z4mwSdcLoc\&t=1250s Accessed on 18.May.2019.

(2019). Neil Gaiman answers top book club questions / The ocean at the end of the lane. (ca. $20 \mathrm{~min} 36 \mathrm{~s}$ ). In https://www.youtube.com/watch?v=skH45WFljQ Accessed on 18. May.2019.

PIGLIA, Ricardo (2011). "Theses on the short story". New Left Review. 70(1), 6366, Jul-Ago. 